\title{
Article \\ Trans-Cinnamaldehyde Attenuates Enterococcus faecalis Virulence and Inhibits Biofilm Formation
}

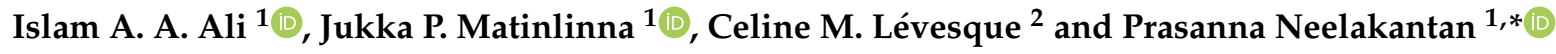 \\ 1 Faculty of Dentistry, The University of Hong Kong, Hong Kong, China; u3004980@connect.hku.hk (I.A.A.A.); \\ jpmat@hku.hk (J.P.M.) \\ 2 Faculty of Dentistry, University of Toronto, Toronto, ON M5G 1G6, Canada; \\ Celine.Levesque@dentistry.utoronto.ca \\ * Correspondence: prasanna@hku.hk; Tel.: +852-2859-0581
}

Citation: Ali, I.A.A.; Matinlinna, J.P.;

Lévesque, C.M.; Neelakantan, P.

Trans-Cinnamaldehyde Attenuates

Enterococcus faecalis Virulence and Inhibits Biofilm Formation. Antibiotics 2021, 10, 702. https://doi.org/

10.3390/antibiotics10060702

Academic Editor:

Lamprini Karygianni

Received: 25 May 2021

Accepted: 9 June 2021

Published: 11 June 2021

Publisher's Note: MDPI stays neutral with regard to jurisdictional claims in published maps and institutional affiliations.

Copyright: () 2021 by the authors. Licensee MDPI, Basel, Switzerland. This article is an open access article distributed under the terms and conditions of the Creative Commons Attribution (CC BY) license (https:// creativecommons.org/licenses/by/ $4.0 /)$.

\begin{abstract}
Enterococcus faecalis as an important nosocomial pathogen is critically implicated in the pathogenesis of endocarditis, urinary tract, and persistent root canal infections. Its major virulence attributes (biofilm formation, production of proteases, and hemolytic toxins) enable it to cause extensive host tissue damage. With the alarming increase in enterococcal resistance to antibiotics, novel therapeutics are required to inhibit E. faecalis biofilm formation and virulence. Trans-cinnamaldehyde (TC), the main phytochemical in cinnamon essential oils, has demonstrated promising activity against a wide range of pathogens. Here, we comprehensively investigated the effect of TC on planktonic growth, biofilm formation, proteolytic and hemolytic activities, as well as gene regulation in E. faecalis. Our findings revealed that sub-inhibitory concentrations of TC reduced biofilm formation, biofilm exopolysaccharides, as well as its proteolytic and hemolytic activities. Mechanistic studies revealed significant downregulation of the quorum sensing $f s r$ locus and downstream gelE, which are major virulence regulators in E. faecalis. Taken together, our study highlights the potential of TC to inhibit E. faecalis biofilm formation and its virulence.
\end{abstract}

Keywords: biofilms; Enterococcus faecalis; quorum sensing; trans-cinnamaldehyde

\section{Introduction}

The Gram-positive bacterium Enterococcus faecalis is a leading cause of endocarditis, urinary tract, surgical wound, and persistent dental root canal infections [1]. Although a commensal of the gastrointestinal tract in humans and animals [2], E. faecalis is known for its virulence attributes including biofilm formation, production of proteolytic enzymes, and antimicrobial resistance, which complicate the treatment of associated infections [3-5].

The biofilm mode of growth is a survival strategy adopted by microbial cells, thereby securing a higher tolerance to antimicrobials compared with their planktonic counterparts $[6,7]$. In addition to the slow growth rate of the resident microbes, altered chemical microenvironments and secretion of a protective extracellular polymeric matrix are responsible for the tolerance of biofilms to antimicrobials [8]. As a result, higher doses of antimicrobials are required to clear microbes, thus placing a strong selective pressure to develop resistance [9]. Furthermore, sub-inhibitory concentrations of antibiotics such as ampicillin and tetracycline resulted in enhanced E. faecalis biofilm development and increased expression of adhesion and biofilm-associated genes [10-12]. Once biofilms are established, they pose extraordinary challenges in treatment, as conventional antibiotics demonstrate only limited activity against biofilms. It has been shown that $E$. faecalis biofilms are tolerant to ampicillin and vancomycin [13]. Moreover, ampicillin, ceftaroline, ceftriaxone, and gentamicin, used alone or in combination, failed to reduce the viability and perturb the architecture of E. faecalis biofilms [14]. Therefore, interfering with biofilm development during its early stages and attenuating bacterial virulence are consid- 
ered promising, innovative, and high-value strategies to avoid the therapeutic challenges associated with recalcitrant $E$. faecalis-mediated infections.

Regulation of bacterial virulence is mediated by quorum sensing (QS) pathways $[15,16]$, wherein the population behavior is synchronized, and the expression of regulatory genes is altered in a population density dependent manner [15,17]. Attenuation of bacterial pathogenicity without affecting bacterial growth is the hallmark of QS quenching as a therapeutic strategy [16]. Therefore, identifying novel anti-QS agents should be prioritized to combat biofilm-mediated infections.

Medicinal plants have a vast repertoire of biologically active compounds that are widely used in pharmaceuticals $[18,19]$. Such compounds protect plants against pathogens in their natural settings [20]. Interestingly, several phytocompounds have demonstrated anti-QS activity at non-lethal concentrations, and thus can suppress bacterial pathogenicity without triggering resistance phenotypes [21,22]. Trans-cinnamaldehyde (TC) is an aromatic aldehyde that predominately exists in cinnamon essential oils (EOs) [23,24]. It has been shown to have antimicrobial and antibiofilm activities against a wide range of bacterial pathogens including Pseudomonas aeruginosa [25,26], Escherichia coli [27,28], Staphylococcus aureus [29,30], Staphylococcus epidermidis [31], and Streptococcus mutans [32]. There is some evidence to show that TC inhibits growth of E. faecalis [33-35], without inducing an adaptive phenotype [34].

Here, we interrogated if sub-inhibitory concentrations of TC could inhibit E. faecalis biofilm development and virulence in vitro. The results of this study demonstrate the potential of TC to inhibit the virulence attributes of E. faecalis including biofilm formation and hemolytic and proteolytic activities at sub-inhibitory concentrations. The anti-virulence effect of TC is possibly mediated via down-regulation of the quorum sensing fsr locus and its downstream gelE gene.

\section{Materials and Methods}

\subsection{Bacterial Strains, Growth Conditions, and Chemicals}

E. faecalis reference strains OG1RF $\left(\mathrm{Cyl}^{-}\right)$and ATCC $29212\left(\mathrm{Cyl}^{+}\right)$were routinely maintained on horse blood agar. All the experiments were performed using the strain OG1RF except the hemolysis assay, which was performed using the strain ATCC 29212, because the latter strain is known to be hemolytic as it harbors the cytolysin operon $[36,37]$. Insertion deletion mutants of the fsr locus (TX 5241 and TX 5242) and gelE gene (TX 5128) of the strain OG1RF were also used [38,39]. For all experiments, planktonic suspensions were prepared from an overnight culture grown in brain heart infusion (BHI) broth at $37^{\circ} \mathrm{C}$. TC (99\% purity) and dimethyl sulfoxide (DMSO) were purchased from Sigma Aldrich (St. Louis, MO, USA). All the experiments were performed in triplicates on three independent occasions.

\subsection{Planktonic Growth Assessment}

The antimicrobial susceptibility of E. faecalis to TC was investigated by determining the minimal inhibitory concentration (MIC) using the broth microdilution assay according to CLSI guidelines [40]. Planktonic suspensions $\left(10^{6} \mathrm{CFU} / \mathrm{mL}\right)$ were added to microplate wells containing two-fold serially diluted TC $(0.059-15 \mathrm{mM})$ in $0.5 \%$ (vol/vol) DMSO. After incubation, the MIC was determined as the lowest concentration of TC that inhibited visible bacterial growth. To investigate the effects of sub-inhibitory (sub-MIC) concentrations of TC on bacterial growth in a time-dependent manner, planktonic cells were incubated with sub-MICs of TC (MIC/8, MIC/4 and MIC/2) in a 96-well polystyrene plate at $37^{\circ} \mathrm{C}$. Growth was determined by measuring the optical density (OD $595 \mathrm{~nm}$ ) of the suspensions every $2 \mathrm{~h}$ using a microplate reader (SpectraMax M2, Molecular Devices, LLC, San Jose, CA, USA). 


\subsection{Biofilm Formation Assays}

Sub-MICs of TC in BHI broth were inoculated with planktonic suspensions to achieve a final bacterial concentration of $10^{6} \mathrm{CFU} / \mathrm{mL}$ [41] and incubated at $37^{\circ} \mathrm{C}$ for $24 \mathrm{~h}$ without agitation [30,32]. After incubation, the planktonic supernatant was carefully removed, and the biofilms were gently washed three times with sterile phosphate-buffered saline (PBS) to remove the non-adherent cells [42]. The effects of TC on E. faecalis biofilm formation was evaluated by quantifying the viable cell counts, metabolic activity, and biomass of developed biofilms.

\subsubsection{Quantification of Viable Cell Counts}

Cell counts were determined using the colony forming units (CFUs) assay. The biofilms were collected by vigorous scraping and pipetting. The collected biofilm suspensions were serially diluted and plated on blood agar. The colonies were counted after incubation at $37^{\circ} \mathrm{C}$ for $48 \mathrm{~h}$.

\subsubsection{Assessment of Biofilm Metabolic Activity}

To assess the biofilm metabolic activity, a reaction solution of PBS, $1 \mathrm{mg} / \mathrm{mL}$ of XTT (2,3-bis(2-methoxy-4-nitro-5-sulfo-phenyl)-2H-tetrazolium-5-carboxanilide), and menadione $(70 \mu \mathrm{g} / \mathrm{mL})$ was freshly prepared at a ratio of 79:20:1. Two hundred microliters of the reaction solution was added to the wells and incubated in dark conditions for $3 \mathrm{~h}$ at $37^{\circ} \mathrm{C}$ [43]. After incubation, $100 \mu \mathrm{L}$ of the supernatant was transferred to a new plate and the absorbance was measured at $492 \mathrm{~nm}$.

\subsubsection{Biomass Quantification}

The biomass of developed biofilms was quantified using the crystal violet assay [44]. Briefly, biofilms were stained with $0.1 \%$ (wt/vol) crystal violet (CV) dye for $10-15 \mathrm{~min}$. After staining, the biofilms were washed with sterile PBS to remove the excess dye and left to dry for $15 \mathrm{~min}$ at room temperature. The retained dye was solubilized with $95 \%$ ( $\mathrm{vol} / \mathrm{vol})$ ethanol for $10 \mathrm{~min}$ and the absorbance of the supernatant was measured at $570 \mathrm{~nm}$.

\subsection{Confocal Microscopic Imaging of Biofilms}

Biofilms were developed on plastic coverslips (diameter $=13 \mathrm{~mm}$, thickness $=0.2 \mathrm{~mm}$ ) (Nunc Thermanox TM, Thermo Fisher Scientific, Waltham, MA, USA) in the presence or absence of sub-MICs of TC at $37{ }^{\circ} \mathrm{C}$ for $24 \mathrm{~h}$. After incubation, the biofilms were gently washed with sterile PBS to remove the non-adherent cells, and stained using BacLight viability kit TM (Thermo Fisher Scientific) for $30 \mathrm{~min}$. The biofilms were examined using an oil-immersion objective lens $(\times 60)$ and imaged by confocal laser scanning microscopy (CLSM; Fluoview FV 1000, Olympus, Tokyo, Japan) at five randomly selected points. The biofilm images were analyzed using the Cell-C software to calculate the attached bacterial cells [45].

\subsection{Quantification of Biofilm Exopolysaccharides}

Biofilm exopolysaccharides in sub-MICs TC-treated biofilms were quantified using the standard phenol sulfuric acid method [46]. Biofilms were allowed to develop in the presence or absence of sub-MICs of TC in a 96-well polystyrene plate at $37^{\circ} \mathrm{C}$ for $24 \mathrm{~h}$. After incubation, the planktonic supernatant was carefully removed, and the biofilms were washed with sterile PBS. Deionized water $(20 \mu \mathrm{L}), 5 \%$ phenol solution $(20 \mu \mathrm{L})$ (Sigma Aldrich, St. Louis, MO, USA), and $98 \%$ sulfuric acid $(100 \mu \mathrm{L})$ were added to the wells and incubated at $90^{\circ} \mathrm{C}$ for $30 \mathrm{~min}$ [47]. The absorbance was measured at $492 \mathrm{~nm}$ using a microplate reader, and the concentration of biofilm exopolysaccharides was determined using a standard curve generated using different glucose concentrations $(0,50,200,500$, and $1000 \mu \mathrm{g} / \mathrm{mL}$ ). 


\subsection{Extracellular Protease Production}

The activity of extracellular proteases produced by E. faecalis was evaluated using the gelatinase plate assay [48]. Briefly, OG1RF planktonic cells $\left(10^{7} \mathrm{CFU} / \mathrm{mL}\right)$ treated with sub-MICs of TC (final bacterial concentration of $10^{6} \mathrm{CFU} / \mathrm{mL}$ ) were spot inoculated on agar supplemented with $5 \%(w t / v o l)$ gelatin and incubated at $37^{\circ} \mathrm{C}$ for $24 \mathrm{~h}$. The $f_{s} r$ and gelE mutants were used as negative controls. The diameter of opaque zones surrounding the bacterial colonies was measured to determine the effect of TC on extracellular proteases activity.

\subsection{Hemolytic Activity Analysis}

The effect of TC on E. faecalis hemolytic activity was determined using a previously described protocol with minor modifications [34]. Horse erythrocytes were collected from defibrinated horse blood after centrifugation $(500 \times g, 10 \mathrm{~min})$ and washed three times with sterile PBS. The planktonic cells of the strain ATCC $29212\left(10^{7} \mathrm{CFU} / \mathrm{mL}\right)$ were incubated with or without sub-MICs of TC (final bacterial concentration of $10^{6} \mathrm{CFU} / \mathrm{mL}$ ) in the presence of $4 \%(\mathrm{vol} / \mathrm{vol})$ horse erythrocytes at $37^{\circ} \mathrm{C}$ for $24 \mathrm{~h}$. Our preliminary results showed similar MICs of TC against the strains OG1RF and ATCC 29212. After incubation, control and TC-treated cultures were centrifuged, and $100 \mu \mathrm{L}$ of the supernatant was transferred to a 96-well polystyrene plate before measuring the absorbance at $550 \mathrm{~nm}$ using a microplate reader. Parallel experiments were carried out following the previously described procedures to investigate the effect of TC and its vehicle (0.5\% DMSO) on horse erythrocytes in the absence of E. faecalis ATCC 29212.

\subsection{Gene Expression Analysis of TC-Treated Biofilms}

To study the effects of TC on the expression of quorum sensing-, virulence-, and cell division-associated genes, E. faecalis biofilms were allowed to develop in the presence or absence of TC (MIC/8) in a sterile polystyrene plate at $37^{\circ} \mathrm{C}$ for $24 \mathrm{~h}$. After incubation, the planktonic supernatant was carefully removed, and the biofilms were washed with sterile PBS. Biofilm suspensions were centrifuged $(9500 \times g, 10 \mathrm{~min})$, and the collected cells were lysed using lysozyme supplemented with mutanolysin as described previously [49]. Total RNA was extracted using RNeasy Mini Kit (Qiagen, Hilden, Germany) according to the manufacturers' instructions, and the complementary DNA (cDNA) was prepared from the RNA template using High-Capacity cDNA Reverse Transcription Kit TM (Applied Biosystems, Foster City, CA, USA).

Quantitative real-time PCR (qRT-PCR) reactions were run on ABI Step One Plus TM Real-Time PCR System (Applied Biosystems, Foster City, CA, USA). The housekeeping gene $23 \mathrm{~S}$ rRNA was used as an internal control to which the expression levels of the tested genes were normalized. Relative gene expression was determined by $2^{-\Delta \Delta \mathrm{CT}}$ method [50]. The sequences of primers used in this study are listed in Table S1 [51,52].

\subsection{Statistical Analysis}

Data from all the phenotypic assays were analyzed using one-way ANOVA and posthoc Dunnett's test. Student's t-test was used to analyze the effect of TC on gene expression. The analyses were performed using IBM SPSS Statistics (Version 26.0, Armonk, NY, USA). A $p$-value $\leq 0.05$ was considered statistically significant.

\section{Results and Discussion}

Cinnamon bark EOs contain TC as the main constituent (65-90\%) [53,54], in addition to other constituents such as eugenol, linalool, caryophyllene oxide, and cinnamaldehyde derivatives (such as cinnamyl acetate, methoxycinnamaldehyde, and cinnamic acid) in small proportions [53,55]. It has been demonstrated that TC is responsible for the antibacterial activity of cinnamon bark EOs [56]. Indeed, it is possible that the presence of a vast array of phytocompounds improves the overall antimicrobial activity of EOs. For instance, a synergistic interaction has been reported between TC and cinnamic acid 
against Salmonella pullorum [57]. On the other hand, constituents such as $\alpha$-pinene and o-anisaldehyde showed additive and indifferent interactions with TC, respectively [57]. However, such findings cannot be generalized to other constituents in cinnamon EOs as eugenol and cinnamyl acetate demonstrated no antibacterial activity against a panel of Gram-positive and Gram-negative bacteria at $1 \mathrm{mg} / \mathrm{mL}$ [58]. In addition, TC and cinnamon bark oil demonstrated similar antibacterial activity, as shown by their ability to kill $P$. aeruginosa after treatment with $1 \times$ MIC within 1.3 and $2 \mathrm{~h}$, respectively [59]. These results confirm that TC is the major determinant of the antibacterial activity of cinnamon EOs. Notwithstanding these findings, the overarching goal of this work was to determine the effects of pure TC on biofilm inhibition and virulence attributes of E. faecalis.

\subsection{Sub-Inhibitory Concentrations of TC inhibit E. faecalis Biofilm Formation}

First, we investigated the antibacterial activity of TC against $E$. faecalis by determining its MIC. The results demonstrated that TC inhibited planktonic growth of the OG1RF strain at $3.7 \mathrm{mM}$. The $0.5 \%$ DMSO in all TC concentrations had no significant effect on planktonic growth (data not shown). Ferro et al. demonstrated that TC inhibited the planktonic growth of E. faecalis ATCC 19433 and clinical strains at $250 \mu \mathrm{g} / \mathrm{mL}$ (1.88 mM) [34], which is lower than the concentration reported in our study. A difference in the tested strains may explain such a variation. TC has been shown to inhibit the planktonic growth of other bacterial species such as S. aureus [34], Streptococcus pyogenes [55], and S. epidermidis [31], at concentrations close to that observed in this study. The growth kinetics study showed that TC at MIC / 2 concentration $(1.88 \mathrm{mM})$ significantly reduced the planktonic growth by at least $32 \%(p \leq 0.01$, Figure 1$)$, while TC at MIC $/ 4(0.94 \mathrm{mM})$ significantly affected the planktonic growth up to $20 \mathrm{~h}$ of incubation ( $p \leq 0.05$, Figure 1$)$. By contrast, the MIC $/ 8$ concentration $(0.47 \mathrm{mM})$ had no significant effect on planktonic growth $(p>0.05$, Figure 1$)$. The estimated generation time was $61 \mathrm{~min}$ for the control planktonic culture, while it was 55,63 , and $100 \mathrm{~min}$ for TC-treated cultures at $0.47,0.94$, and $1.88 \mathrm{mM}$, respectively.

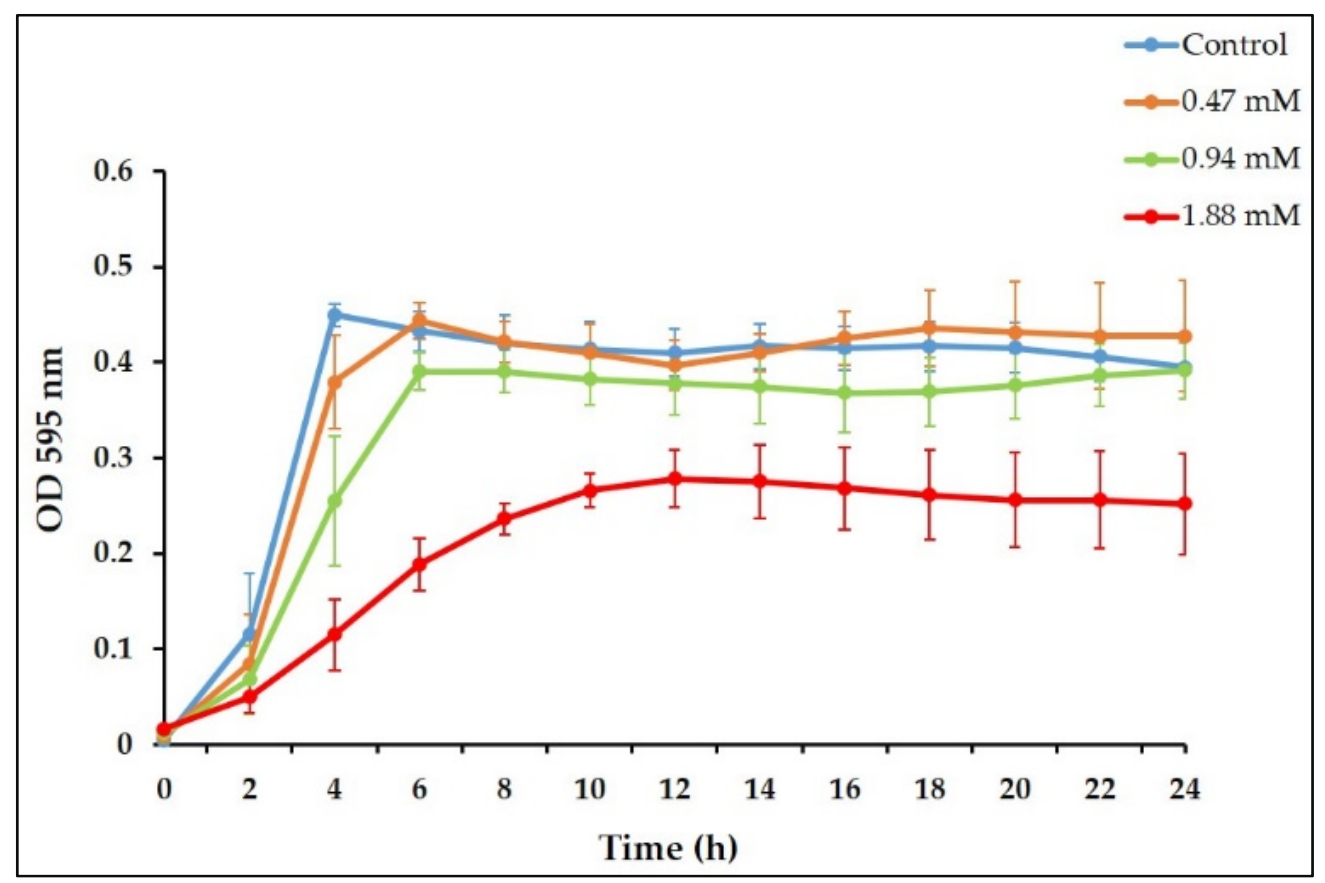

Figure 1. Effect of sub-minimal inhibitory concentrations (MICs) of trans-cinnamaldehyde (TC) on planktonic growth kinetics of E. faecalis. The growth kinetics plot shows that TC at $0.47 \mathrm{mM}$ had no significant effect on planktonic growth over the $24 \mathrm{~h}$ period, compared with untreated controls $(p>0.05)$. 
We then investigated the effect of TC on E. faecalis biofilm formation by evaluating the viable cell counts, metabolic activity, and biomass of biofilms developed in the presence or absence of sub-MICs of TC. The results showed a significant dose-dependent reduction in $\log _{10} \mathrm{CFU} / \mathrm{mL}$ of biofilm cells ( $p \leq 0.05$, Figure 2a). Ferro et al. demonstrated that TC at MIC $/ 2$ and MIC/4 decreased the number of E. faecalis cells attached to a catheter model [34]. A similar pattern was observed in the XTT assay, which showed a reduction in the metabolic activity by 12,31 , and $51 \%$ in biofilms developed at $0.47,0.94$, and $1.88 \mathrm{mM}$, respectively. This reduction was significant at 0.94 and $1.88 \mathrm{mM}(p \leq 0.01$, Figure $2 \mathrm{~b})$, and insignificant at $0.47 \mathrm{mM}(p>0.05$, Figure $2 \mathrm{~b})$. These findings indicate that $0.47 \mathrm{mM}$ TC potentially interferes with the adhesion of planktonic cells, thus decreasing the number of biofilm cell counts as shown by the CFUs assay, without affecting their viability as demonstrated by the metabolic activity assay.
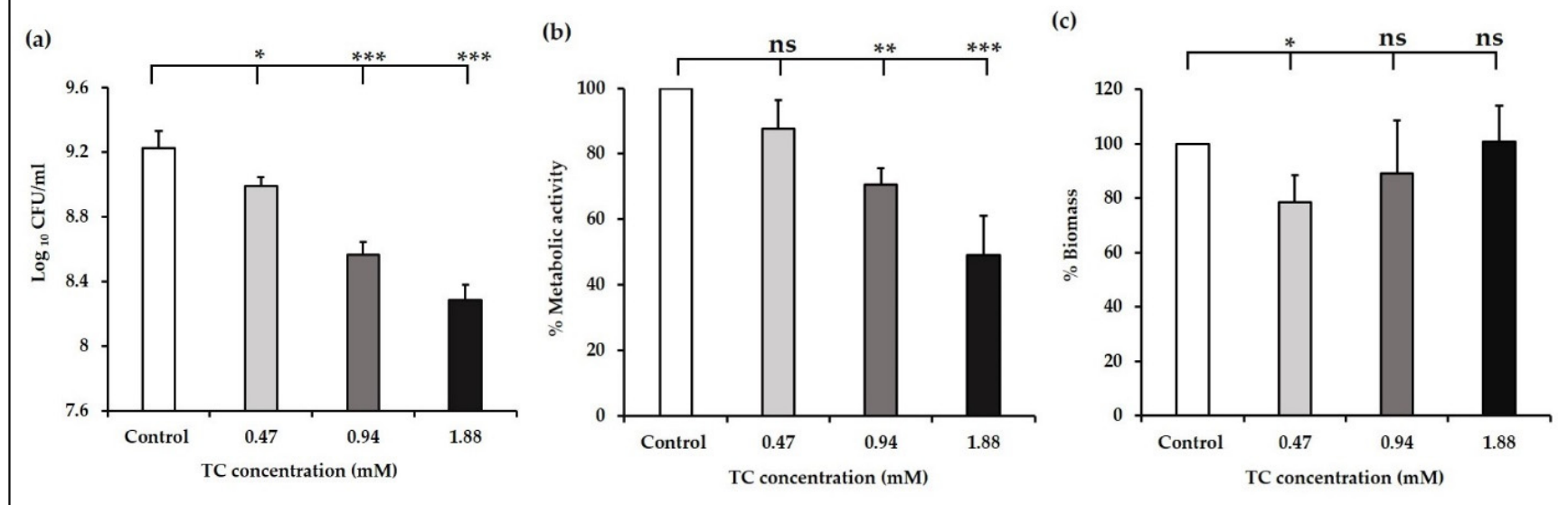

Figure 2. (a) Cell count, (b) metabolic activity, and (c) biomass of E. faecalis biofilms developed at sub-MICs of TC. Cell count is expressed in $\log _{10} \mathrm{CFU} / \mathrm{mL}$, while the metabolic activity and biomass are expressed relative to the control (100\%). * denotes $p \leq 0.05,{ }^{* *}$ denotes $p \leq 0.01,{ }^{* * *}$ denotes $p \leq 0.001$, ns denotes non-significant difference compared with control $(p>0.05)$.

Agreement in the results of XTT and CFUs assay was observed at 0.94 and $1.88 \mathrm{mM}$, while such an agreement was not observed at $0.47 \mathrm{mM}$. Variation between the results of XTT and CFU assays has been addressed previously, wherein the XTT absorbance showed a linear response when the logarithm of cell numbers ranges from 4.5 to 7.5 [60]. Furthermore, a substantial increase in XTT absorbance has been reported above $10^{8}$ cells $/ \mathrm{mL}$ compared with a steady increase in XTT absorbance at a lower cell number [61]. Thus, a clear-cut linear relation between XTT absorbance and cell numbers cannot be necessarily assumed and this methodological issue should be taken into consideration when such studies are performed.

We then evaluated the biomass of E. faecalis biofilms developed at sub-MICs of TC using the $\mathrm{CV}$ assay. A concentration of $0.47 \mathrm{mM}$ significantly reduced the biomass compared with control ( $p \leq 0.01$, Figure 2c). The biomass of biofilms developed at 0.94 and $1.88 \mathrm{mM}$ was not significantly different from the control $(p>0.05$, Figure $2 \mathrm{c})$, which agrees with the results reported by Ferro et al. [34], wherein TC had no effect on biofilm formation by clinical E. faecalis isolates. Despite the reduction in the number of viable biofilm cells at $1.88 \mathrm{mM}$ observed in our study, no corresponding reduction in the biomass was observed. This is similar to previously reported findings, wherein MIC/2 of TC significantly reduced the number of $S$. aureus viable biofilm cells without being able to reduce the overall biomass [34]. Instead, the biomass was increased probably because of an accumulation of dead cells [34].

The observed reduction in biofilm formation by E. faecalis at a sub-MIC of TC without inhibiting planktonic growth reduces the selective pressure to enhance the emergence of resistance phenotype. This should be taken into consideration, along with previous findings 
demonstrating that E. faecalis did not develop resistance to TC, while it developed resistance to antibiotics such as ciprofloxacin [34] and antiseptics such as chlorhexidine [61-63].

Reduction of the biofilm biomass by TC at $0.47 \mathrm{mM}$, as observed in our study, corroborate with previous studies, wherein sub-MICs of TC reduced biofilm formation by $S$. mutans [32], S. pyogenes [64], and P. aeruginosa $[25,26,65]$. In some of these studies, reduction in biofilm formation was associated with suppression of QS pathways in the relevant microorganisms [32,65]. Therefore, we hypothesize that reduction of E. faecalis biofilm formation by TC at $0.47 \mathrm{mM}$ could be mediated via suppression of QS systems. E. faecalis has three main QS systems-Fsr, Cytolysin, and LuxS [66]. The Fsr QS system contributes to biofilm formation via production of gelatinase [67]. Hence, we tested the effect of TC at $0.47 \mathrm{mM}$ on biofilm formation using two fsr mutants TX 5241 and TX 5242, which are characterized by insertion deletion of $f s r B$ and $f s r C$ genes, respectively $[38,39]$. The results showed that TC was unable to reduce biofilm formation by the $f s r$ mutants $(p>0.05$, Figure 3), thus demonstrating that the Fsr QS system is targeted by the biofilm inhibitory concentration of TC and the effect of TC on E. faecalis biofilm formation is not evident when the $f s r$ QS genes are inactivated.

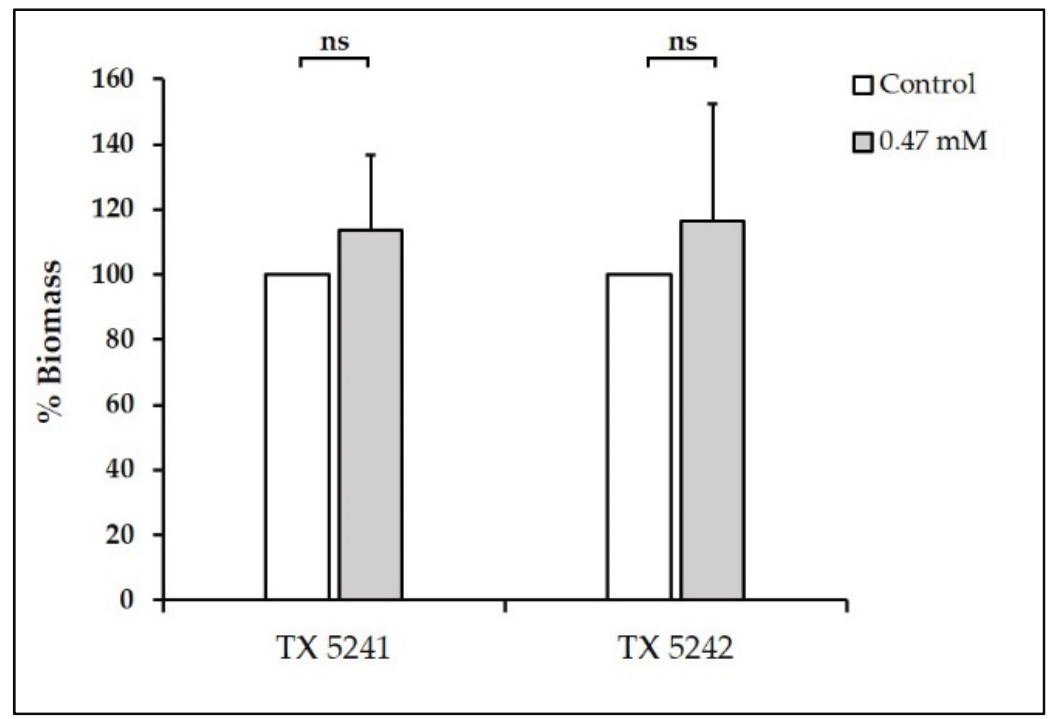

Figure 3. Effect of TC $(0.47 \mathrm{mM})$ on biofilm formation by the OG1RF and $f s r$ mutants (insertion deletion $f_{s} r B$ and $f_{s} r C$ mutants, TX 5241 and TX 5242, respectively). In each tested strain, the biomass developed in the presence of TC was normalized to its respective control (100\%). ns denotes no significant difference compared with control $(p>0.05)$.

To elucidate the antibiofilm effect of TC on E. faecalis, we investigated the overall structure of E. faecalis biofilms using CLSM. There were considerable areas of the substrate devoid of biofilm in TC groups (Figure 4a), wherein the mean attached bacterial cells $\left(2-3.6 \times 10^{3}\right.$ cells $\left./ \mathrm{mm}^{2}\right)$ were significantly lower compared with those in control biofilms $\left(13 \times 10^{3}\right.$ cells $\left./ \mathrm{mm}^{2}\right)(p \leq 0.001$, Figure $4 \mathrm{~b})$. Similar results have been demonstrated for $S$. mutans and S. pyogenes biofilms developed at sub-inhibitory concentrations of TC [32,64]. 


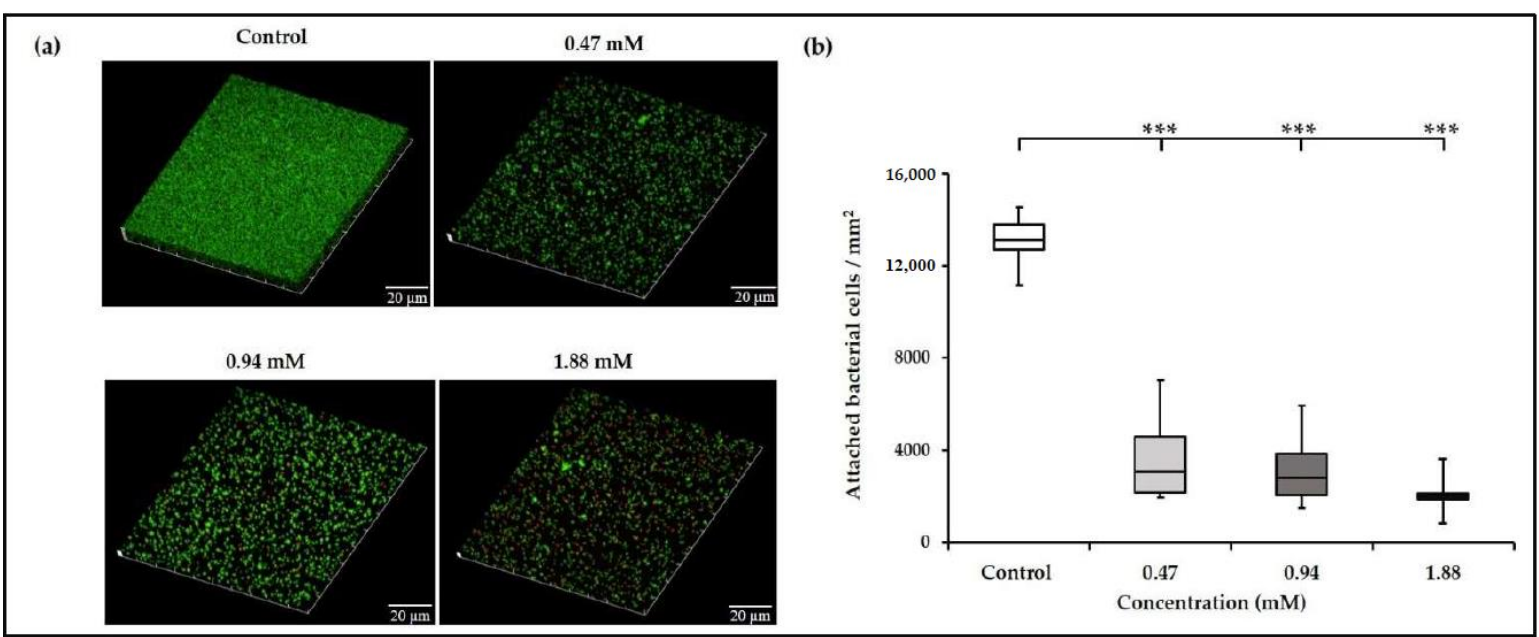

Figure 4. Confocal laser scanning microscopy (CLSM) investigation of E. faecalis biofilms developed in the presence or absence of TC. (a) Three-dimensionally reconstructed CLSM images showing reduction of E. faecalis biofilm formation by TC. At sub-MICs of TC, the biofilm structure was disrupted and demonstrated reduced density compared with intact and dense control biofilms. (b) Sub-MICs of TC significantly reduced the total number of attached bacterial cells $/ \mathrm{mm}^{2}$ compared with control, indicating the inhibition of microbial adhesion and biofilm formation. ${ }^{* *}$ denotes $p \leq 0.001$.

\subsection{Sub-Inhibitory Concentration of TC Reduced E. faecalis Biofilm Exopolysaccharides}

Biofilms are structurally complex communities, in which the cells are embedded in an extracellular polymeric substance (EPS), which contains polysaccharides, proteins, and nucleic acids as its major constituents [68,69]. Polysaccharides contribute to bacterial adhesion, aggregation, biofilm stability, nutrients acquisition, and protection against antimicrobials [61]. Therefore, we investigated the effect of sub-MICs of TC on exopolysaccharides content of E. faecalis biofilms. Glucose standard curve used to quantify the biofilm exopolysaccharides showed goodness-of-fit determined by correlation coefficient $\mathrm{R}^{2}=0.995-0.999$. The results demonstrated a significant reduction in the exopolysaccharides of biofilms developed at $0.47 \mathrm{mM}$ of TC $(75 \pm 15 \mu \mathrm{g} / \mathrm{mL})$ compared with control biofilms $(107 \pm 28 \mu \mathrm{g} / \mathrm{mL})(p \leq 0.01)$. Such a reduction in exopolysaccharides provides a plausible explanation of the reduced biomass at $0.47 \mathrm{mM}$ as shown by the $\mathrm{CV}$ assay.

The results of exopolysaccharides and metabolic activity assays in our study support the previously reported findings that TC inhibited biofilm formation by reducing exopolysaccharides production, without affecting the viability of biofilm cells [70]. TC reduced exopolysaccharides production by Listeria monocytogenes in accordance with the results of our study [71]. In our study, the biofilm exopolysaccharides at $0.94(119 \pm 21 \mu \mathrm{g} / \mathrm{mL})$ and $1.88 \mathrm{mM}(136 \pm 38 \mu \mathrm{g} / \mathrm{mL})$ were not significantly different from control biofilms $(p \geq 0.05)$, which explains the insignificant difference in biomass at 0.94 and $1.88 \mathrm{mM}$ compared with control biofilms as shown by CV assay (Figure 2c).

\subsection{TC Reduced the Proteolytic and Hemolytic Activities of E. faecalis}

Extracellular proteases are putative virulence factors, which play an important role in the pathogenicity of E. faecalis [72]. Gelatinase and serine protease contribute to E. faecalis biofilm formation [68] and degradation of host tissues [73,74]. Thus, we asked if sub-MICs of TC could affect the activity of such proteases. To validate the results of the extracellular protease activity assay, no opaque zones were observed surrounding the colonies of the gelatinase-negative $f s r$ (TX 5241 and TX 5242) and gelE (TX 5128) mutants inoculated on gelatin-supplemented agar (Figure S1). The results showed that TC at 0.47 and $1.88 \mathrm{mM}$ significantly decreased the diameter of proteolytic zones surrounding the bacterial colonies (23.5 $\pm 0.9 \mathrm{~mm}$ in $0.47 \mathrm{mM}$ and $22.3 \pm 0.9 \mathrm{~mm}$ in $1.88 \mathrm{mM}$ groups versus $24.5 \pm 0.8 \mathrm{~mm}$ in control group, $p \leq 0.05)$. By contrast, TC at $0.94 \mathrm{mM}$ had no significant effect on the 
proteolytic activity $(23.6 \pm 0.8 \mathrm{~mm}, p>0.05)$. It has been shown that $\mathrm{TC}$ reduced protease activity of $S$. pyogenes [64].

Cytolysin (or hemolysin) is an exotoxin that lyses human erythrocytes, intestinal epithelial, and retinal cells, and is thereby implicated in the pathogenesis of enterococcal infections [75]. The widespread prevalence of hemolysis phenotype in clinical isolates emphasizes cytolysin as a promising target for future development of anti-infective agents [76,77]. For instance, a positive hemolytic activity has been observed in $60 \%$ of $E$. faecalis strains of saliva, plaque, and root canal origin [78]. Therefore, we investigated the effect of TC on the hemolytic activity of E. faecalis. The results showed that TC reduced the hemolytic activity of E. faecalis by $21 \pm 9 \%, 39 \pm 12 \%$, and $64 \pm 5 \%$ at $0.47,0.94$, and $1.88 \mathrm{mM}$ respectively, compared with control $(p \leq 0.001)$. This corroborates with a previous finding that sub-MIC of TC reduced the hemolytic activity of a clinical isolate of E. faecalis [34]. It is interesting to note that sub-MICs of TC also reduced hemolysis induced by S. aureus [34] and $P$. aeruginosa [26], indicating that TC has the potential to inhibit virulence in a wide range of Gram-positive and Gram-negative pathogens. In bacteria-free experiments, although TC at the tested concentrations significantly increased the hemolysis of horse erythrocytes compared with those receiving no treatment $(p \leq 0.05)$, this effect could be owing to the vehicle $0.5 \%$ DMSO, which significantly increased the hemolysis of horse erythrocytes $(p \leq 0.05)$, without being significantly different from TC groups $(p>0.05)$. However, there was no difference in the hemolysis of horse erythrocytes receiving no treatment or $0.5 \%$ DMSO $(p>0.05)$ in the presence of E. faecalis ATCC 29212.

\subsection{TC Suppress the Fsr Quorum Sensing Pathway and the Downstream gelE Gene}

Based on the results of the observed phenotypes, sub-inhibitory concentrations of TC reduced E. faecalis biofilm formation, altered the structure of developed biofilms, and attenuated its proteolytic and hemolytic activities. Therefore, in order to understand the underlying mechanisms, we investigated the effect of TC on the expression of quorum sensing-, virulence-, and cell division-associated genes using qRT-PCR. The interest in the fsr locus arises from previous findings, which showed that the Fsr system was the only two-component signal transduction system in E. faecalis, which affects biofilm formation when inactivated $[67,79]$. In addition, the Fsr system has an important role in the regulation of surface proteins and several metabolic pathways in E. faecalis [80]. The presence of fsr locus in $100 \%$ of endocarditis isolates and over $50 \%$ of fecal isolates strongly suggests that this system is a promising target to develop non-toxic inhibitors, thus attenuating the pathogenicity of E. faecalis [81].

The $f_{s} r B$ gene encodes a trans-membrane protein that processes a propeptide to generate a peptide pheromone, while the $f s r C$ gene encodes a histidine kinase sensor that responds to the peptide-signaling molecule, phosphorylates its response regulator, and subsequently activates the transcription of the gelE-sprE operon [82]. The Fsr QS system contributes to biofilm formation and virulence of E. faecalis via gelatinase production $[67,83]$. Our results showed that TC at $0.47 \mathrm{mM}$ significantly downregulated the expression of $f_{s} r B$ and $f_{s r} C$ compared with the control ( $p \leq 0.001$, Figure 5). TC has been demonstrated to downregulate the expression of quorum sensing genes in other Gram-positive bacteria such as S. mutans $[32,84]$ and L. monocytogenes [71], indicating that TC has the potential to inhibit virulence in different species through multiple pathways. 


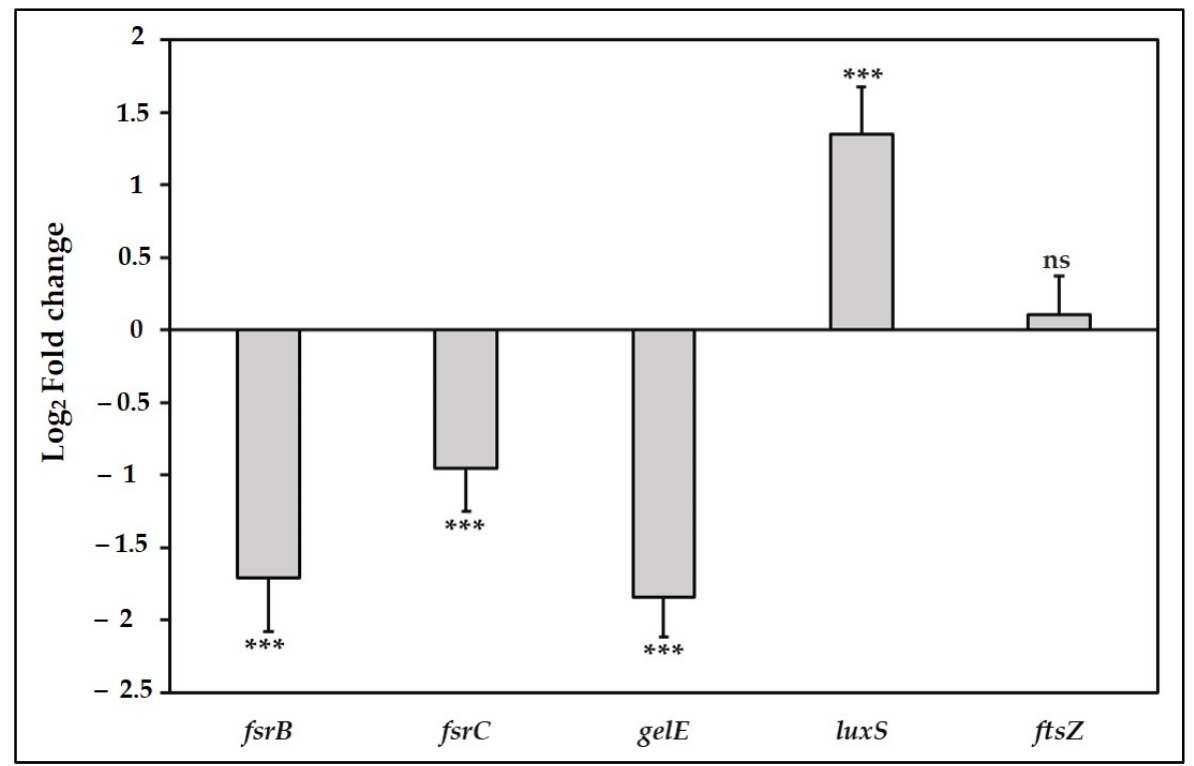

Figure 5. Effect of sub-MIC of TC $(0.47 \mathrm{mM})$ on gene expression in E. faecalis. ${ }^{* * *}$ denotes $p \leq 0.001$, ns denotes no significant difference compared with control $(p>0.05)$.

Downstream to the $f s r$ locus, gelE regulates the production of gelatinase, an extracellular metalloprotease, which contributes to biofilm formation via fratricide mediated cell lysis and release of extracellular DNA [85]. The importance of gelE for E. faecalis pathogenicity was emphasized by its widespread prevalence in isolates from food and clinical sources $[78,86]$. It has been shown that gelE gene is present in $75-100 \%$ of E. faecalis strains isolated from root canal infections $[36,87,88]$. In our study, we observed that the transcription of gelE was significantly downregulated at the concentration $0.47 \mathrm{mM}$ compared with the control ( $p \leq 0.001$, Figure 5). In accordance with our results, TC has been shown to reduce the transcription of speB and las $A$ genes that encode proteases production in S. pyogenes and P. aeruginosa, respectively $[64,65]$. The results of the gene expression analysis corroborate the results of phenotypic biofilm formation assays done on the wildtype OG1RF strain (Figure 2c) and fsr mutants (Figure 3). The findings from these assays collectively support the hypothesis that suppression of the $f s r$ locus and its downstream gelE is a possible mechanism to elucidate the inhibitory effect of TC on biofilm formation in E. faecalis.

The LuxS/Autoinducer-2 (AI-2) dependent QS system is a universal signaling pathway involved in interspecies communication, regulation of virulence factors, and hostmicrobe interactions $[15,89]$. In this system, lux $S$ encodes a metalloenzyme involved in the production of AI-2 [90]. The results in our study showed that a sub-MIC of TC significantly upregulated the expression of $\operatorname{luxS}(p \leq 0.001$, Figure 5). By contrast, expression of $l u x S$ in S. pyogenes and S. mutans was downregulated by TC $[64,84]$. TC did not affect the AI-2 production but reduced the bioluminescence in the Gram-negative Vibrio harveyi by targeting the DNA binding activity of the transcriptional regulator LuxR $[70,91]$. These contradictory results can be explained by differences in the quorum sensing-regulated phenotypes between bacterial species, and even between the strains of the same species [92]. Such strain-related variations have been reported regarding the role of luxS in E. faecalis. While the deletion of $l u x S$ in the strain ATCC 33186 resulted in increased biofilm formation [51], it resulted in opposite effects in the strain ATCC 29212 [93], and this reduction was only significant in 48-h-old biofilms.

Inhibition of cell division is one of the proposed antibacterial mechanisms of action of TC $[55,94]$. Therefore, we studied the effect of TC on the expression of $f t s Z$, which encodes a key cytoplasmic protein in cell division. Our results showed that the sub-MIC of TC did not significantly affect the expression of $f t s Z(p>0.05$, Figure 5). TC has been shown to 
inhibit bacterial cell division by binding to the C-terminal region of FtsZ, thus perturbing the morphology of Z-ring and interfering with its assembly dynamics [95].

To the best knowledge of the authors, this is the first study to provide comprehensive evidence on the concentration-dependent effects of TC on biofilm inhibition, reduction of biofilm exopolysaccharides, and virulence inhibition in E. faecalis. However, we investigated the effect of TC on biofilm formation and virulence factors only in the $f s r$ positive strain OG1RF. Future investigations should be performed on several clinical isolates with different quorum sensing and virulence profiles. Transcription of genes encoding surface adhesins and other virulence determinants after treatment with TC should also be studied in future work. Future studies will also include testing the antibiofilm activity of TC under clinically relevant conditions such as the presence of polymicrobial biofilms and nutrient supplementation.

\section{Conclusions}

The results of this study highlighted that sub-inhibitory concentrations of transcinnamaldehyde reduced $E$. faecalis biofilm formation, altered the structure of developed biofilms, and attenuated the proteolytic and hemolytic activities without inhibiting the bacterial growth, which minimizes the risk of developing resistance. The biofilm inhibitory action of TC is mediated via reduction of biofilm exopolysaccharides and/or downregulation of genes related to the Fsr quorum sensing system in E. faecalis.

Supplementary Materials: The following are available online at https: / www.mdpi.com/article/ 10.3390/antibiotics10060702/s1, Table S1: Sequence of primers used in the qRT-PCR analysis. Figure S1. Extracellular protease activity of the wild-type OG1RF, gelE (TX 5128), fsrB (TX 5241), and fsrC (TX 5242) mutant strains. The presence of opaque zone surrounding the OG1RF strain indicates positive protease activity, while no opaque zones were observed surrounding the fsr or gelE mutants, which indicates negative protease activity.

Author Contributions: Conceptualization, P.N., C.M.L. and I.A.A.A.; methodology, P.N. and I.A.A.A.; formal analysis, I.A.A.A.; investigation, I.A.A.A.; resources, P.N. and J.P.M.; data curation, I.A.A.A.; writing-original draft preparation, I.A.A.A. and P.N.; writing-review and editing, I.A.A.A., P.N., C.M.L. and J.P.M.; supervision, P.N., C.M.L. and J.P.M.; project administration, P.N. All authors have read and agreed to the published version of the manuscript.

Funding: This research was supported by the seed fund from the University of Hong Kong to P.N.

Institutional Review Board Statement: Not applicable.

Informed Consent Statement: Not applicable.

Data Availability Statement: The data presented in this study are openly available in Figshare at https:/ / doi.org/10.25442/hku.14208566.v1.

Acknowledgments: I.A.A.A. is supported by the postgraduate fellowship from the University of Hong Kong, and this study is a part of his doctoral thesis. The authors gratefully acknowledge Professor Barbara E. Murray (Division of Infectious Diseases, Department of Medicine, University of Texas Medical School, Huston, TX, USA) for providing us the $f s r$ mutants of the OG1RF strain. The authors sincerely thank Becky Cheung, Central Research Laboratories, Faculty of Dentistry, The University of Hong Kong for the technical expertise with the confocal microscopic experiment.

Conflicts of Interest: The authors declare no conflict of interest.

\section{References}

1. Ch'ng, J.H.; Chong, K.K.L.; Lam, L.N.; Wong, J.J.; Kline, K.A. Biofilm-associated infection by Enterococci. Nat. Rev. Microbiol. 2019, 17, 82-94. [CrossRef]

2. Ramos, S.; Silva, V.; Dapkevicius, M.L.E.; Igrejas, G.; Poeta, P. Enterococci, from Harmless Bacteria to a Pathogen. Microorganisms 2020, 8, 1118. [CrossRef]

3. Fisher, K.; Phillips, C. The Ecology, Epidemiology and Virulence of Enterococcus. Microbiology 2009, 155, 1749-1757. [CrossRef]

4. Paganelli, F.L.; Willems, R.J.; Leavis, H.L. Optimizing Future Treatment of Enterococcal Infections: Attacking the Biofilm? Trends Microbiol. 2012, 20, 40-49. [CrossRef] [PubMed] 
5. $\quad$ van Harten, R.M.; Willems, R.J.L.; Martin, N.I.; Hendrickx, A.P.A. Multidrug-Resistant Enterococcal Infections: New Compounds, Novel Antimicrobial Therapies? Trends Microbiol. 2017, 25, 467-479. [CrossRef]

6. Römling, U.; Balsalobre, C. Biofilm Infections, Their Resilience to Therapy and Innovative Treatment Strategies. J. Intern. Med. 2012, 272, 541-561. [CrossRef] [PubMed]

7. de la Fuente-Núñez, C.; Reffuveille, F.; Fernández, L.; Hancock, R.E. Bacterial Biofilm Development as a Multicellular Adaptation: Antibiotic Resistance and New Therapeutic Strategies. Curr. Opin. Microbiol. 2013, 16, 580-589. [CrossRef]

8. Sharma, D.; Misba, L.; Khan, A.U. Antibiotics versus Biofilm: An Emerging Battleground in Microbial Communities. Antimicrob. Resist. Infect. Control 2019, 8, 76. [CrossRef]

9. Levy, S.B.; Marshall, B. Antibacterial Resistance Worldwide: Causes, Challenges and Responses. Nat. Med. 2004, 10, S122-S129. [CrossRef]

10. Wilson, C.E.; Cathro, P.C.; Rogers, A.H.; Briggs, N.; Zilm, P.S. Clonal Diversity in Biofilm Formation by Enterococcus faecalis in Response to Environmental Stress Associated with Endodontic Irrigants and Medicaments. Int. Endod. J. 2015, 48, $210-219$. [CrossRef]

11. Kafil, H.S.; Mobarez, A.M.; Moghadam, M.F.; Hashemi, Z.S.; Yousefi, M. Gentamicin Induces efaA Expression and Biofilm Formation in Enterococcus faecalis. Microb. Pathog. 2016, 92, 30-35. [CrossRef]

12. Yu, W.; Hallinen, K.M.; Wood, K.B. Interplay between Antibiotic Efficacy and Drug-Induced Lysis Underlies Enhanced Biofilm Formation at Subinhibitory Drug Concentrations. Antimicrob. Agents Chemother. 2018, 62, e01603-17. [CrossRef] [PubMed]

13. Seneviratne, C.J.; Suriyanarayanan, T.; Swarup, S.; Chia, K.H.B.; Nagarajan, N.; Zhang, C. Transcriptomics Analysis Reveals Putative Genes Involved in Biofilm Formation and Biofilm-associated Drug Resistance of Enterococcus faecalis. J. Endod. 2017, 43, 949-955. [CrossRef]

14. Thieme, L.; Klinger-Strobel, M.; Hartung, A.; Stein, C.; Makarewicz, O.; Pletz, M.W. In vitro synergism and anti-biofilm activity of ampicillin, gentamicin, ceftaroline and ceftriaxone against Enterococcus faecalis. J. Antimicrob. Chemother. 2018, 73, $1553-1561$. [CrossRef] [PubMed]

15. Miller, M.B.; Bassler, B.L. Quorum Sensing in Bacteria. Annu. Rev. Microbiol. 2001, 55, 165-199. [CrossRef]

16. Jiang, Q.; Chen, J.; Yang, C.; Yin, Y.; Yao, K. Quorum Sensing: A Prospective Therapeutic Target for Bacterial Diseases. Biomed. Res. Int. 2019, 2019, 2015978. [CrossRef] [PubMed]

17. Bassler, B.L.; Losick, R. Bacterially Speaking. Cell 2006, 125, 237-246. [CrossRef] [PubMed]

18. Sharifi-Rad, J.; Sureda, A.; Tenore, G.C.; Daglia, M.; Sharifi-Rad, M.; Valussi, M.; Tundis, R.; Sharifi-Rad, M.; Loizzo, M.R.; Ademiluyi, A.O.; et al. Biological Activities of Essential Oils: From Plant Chemoecology to Traditional Healing Systems. Molecules 2017, 22, 70. [CrossRef] [PubMed]

19. Tariq, S.; Wani, S.; Rasool, W.; Shafi, K.; Bhat, M.A.; Prabhakar, A.; Shalla, A.H.; Rather, M.A. A Comprehensive Review of the Antibacterial, Antifungal and Antiviral Potential of Essential Oils and Their Chemical Constituents against Drug-resistant Microbial Pathogens. Microb. Pathog. 2019, 134, 103580. [CrossRef]

20. Iriti, M.; Faoro, F. Chemical Diversity and Defence Metabolism: How Plants Cope with Pathogens and Ozone Pollution. Int. J. Mol. Sci. 2009, 10, 3371-3399. [CrossRef]

21. Nazzaro, F.; Fratianni, F.; Coppola, R. Quorum Sensing and Phytochemicals. Int. J. Mol. Sci. 2013, 14, 12607-12619. [CrossRef]

22. LaSarre, B.; Federle, M.J. Exploiting Quorum Sensing to Confuse Bacterial Pathogens. Microbiol. Mol. Biol. Rev. 2013, 77, 73-111. [CrossRef]

23. Shan, B.; Cai, Y.Z.; Brooks, J.D.; Corke, H. Antibacterial Properties and Major Bioactive Components of Cinnamon Stick (Cinnamomum burmannii): Activity against Foodborne Pathogenic Bacteria. J. Agric. Food. Chem. 2007, 55, 5484-5490. [CrossRef]

24. Kim, Y.G.; Lee, J.H.; Kim, S.I.; Baek, K.H.; Lee, J. Cinnamon Bark Oil and Its Components Inhibit Biofilm Formation and Toxin Production. Int. J. Food Microbiol. 2015, 195, 30-39. [CrossRef]

25. Topa, S.H.; Subramoni, S.; Palombo, E.A.; Kingshott, P.; Rice, S.A.; Blackall, L.L. Cinnamaldehyde Disrupts Biofilm Formation and Swarming Motility of Pseudomonas aeruginosa. Microbiology 2018, 164, 1087-1097. [CrossRef]

26. Ferro, T.A.F.; Souza, E.B.; Suarez, M.A.M.; Rodrigues, J.F.S.; Pereira, D.M.S.; Mendes, S.J.F.; Gonzaga, L.F.; Machado, M.; Bomfim, M.R.Q.; Calixto, J.B.; et al. Topical Application of Cinnamaldehyde Promotes Faster Healing of Skin Wounds Infected with Pseudomonas aeruginosa. Molecules 2019, 24, 1627. [CrossRef] [PubMed]

27. Amalaradjou, M.A.; Narayanan, A.; Baskaran, S.A.; Venkitanarayanan, K. Antibiofilm Effect of Trans-cinnamaldehyde on Uropathogenic Escherichia coli. J. Urol. 2010, 184, 358-363. [CrossRef]

28. Yuan, W.; Yuk, H.G. Effects of Sublethal Thymol, Carvacrol, and Trans-cinnamaldehyde Adaptation on Virulence Properties of Escherichia coli O157:H7. Appl. Environ. Microbiol. 2019, 85, e0271-19. [CrossRef]

29. Jia, P.; Xue, Y.J.; Duan, X.J.; Shao, S.H. Effect of Cinnamaldehyde on Biofilm Formation and sarA Expression by Methicillin-resistant Staphylococcus aureus. Lett. Appl. Microbiol. 2011, 53, 409-416. [CrossRef] [PubMed]

30. Kot, B.; Sytykiewicz, H.; Sprawka, I.; Witeska, M. Effect of Trans-cinnamaldehyde on Methicillin-resistant Staphylococcus aureus Biofilm Formation: Metabolic Activity Assessment and Analysis of the Biofilm-associated Genes Expression. Int. J. Mol. Sci. 2019, 21, 102. [CrossRef] [PubMed]

31. Albano, M.; Crulhas, B.P.; Alves, F.C.B.; Pereira, A.F.M.; Andrade, B.; Barbosa, L.N.; Furlanetto, A.; Lyra, L.; Rall, V.L.M.; Júnior, A.F. Antibacterial and Anti-biofilm Activities of Cinnamaldehyde against S. epidermidis. Microb. Pathog. 2019, 126, 231-238. [CrossRef] [PubMed] 
32. He, Z.; Huang, Z.; Jiang, W.; Zhou, W. Antimicrobial Activity of Cinnamaldehyde on Streptococcus mutans Biofilms. Front. Microbiol. 2019, 10, 2241. [CrossRef]

33. Chang, S.T.; Chen, P.F.; Chang, S.C. Antibacterial Activity of Leaf Essential Oils and Their Constituents from Cinnamomum osmophloeum. J. Ethnopharmacol. 2001, 77, 123-127. [CrossRef]

34. Ferro, T.A.; Araújo, J.M.; Dos Santos Pinto, B.L.; Dos Santos, J.S.; Souza, E.B.; da Silva, B.L.; Colares, V.L.; Novais, T.M.; Filho, C.M.; Struve, C.; et al. Cinnamaldehyde Inhibits Staphylococcus aureus Virulence Factors and Protects against Infection in a Galleria mellonella Model. Front. Microbiol. 2016, 7, 2052. [CrossRef]

35. Ali, I.A.A.; Cheung, B.P.K.; Matinlinna, J.; Lévesque, C.M.; Neelakantan, P. Trans-cinnamaldehyde Potently Kills Enterococcus faecalis Biofilm Cells and Prevents Biofilm Recovery. Microb. Pathog. 2020, 149, 104482. [CrossRef]

36. Zhu, X.; Wang, Q.; Zhang, C.; Cheung, G.S.; Shen, Y. Prevalence, Phenotype, and Genotype of Enterococcus faecalis Isolated from Saliva and Root Canals in Patients with Persistent Apical Periodontitis. J. Endod. 2010, 36, 1950-1955. [CrossRef]

37. Kim, E.B.; Kopit, L.M.; Harris, L.J.; Marco, M.L. Draft Genome Sequence of the Quality Control Strain Enterococcus faecalis ATCC 29212. J. Bacteriol. 2012, 194, 6006-6007. [CrossRef]

38. Qin, X.; Singh, K.V.; Weinstock, G.M.; Murray, B.E. Effects of Enterococcus faecalis fsr Genes on Production of Gelatinase and a Serine Protease and Virulence. Infect. Immun. 2000, 68, 2579-2586. [CrossRef]

39. Qin, X.; Singh, K.V.; Weinstock, G.M.; Murray, B.E. Characterization of Fsr, A Regulator Controlling Expression of Gelatinase and Serine Protease in Enterococcus faecalis OG1RF. J. Bacteriol. 2001, 183, 3372-3382. [CrossRef]

40. CLSI. Methods for Dilution Antimicrobial Susceptibility Tests for Bacteria That Grow Aerobically, 9th ed.; Approved Standard M07-A9; Clinical and Laboratory Standards Institute: Wayne, PA, USA, 2012.

41. Liu, F.; Jin, P.; Gong, H.; Sun, Z.; Du, L.; Wang, D. Antibacterial and Antibiofilm Activities of Thyme Oil against Foodborne Multiple Antibiotics-resistant Enterococcus faecalis. Poult. Sci. 2020, 99, 5127-5136. [CrossRef]

42. Extremina, C.I.; Costa, L.; Aguiar, A.I.; Peixe, L.; Fonseca, A.P. Optimization of Processing Conditions for the Quantification of Enterococci Biofilms using Microtitre-plates. J. Microbiol. Methods 2011, 84, 167-173. [CrossRef]

43. Kalimuthu, S.; Cheung, B.P.K.; Yau, J.Y.Y.; Shanmugam, K.; Solomon, A.P.; Neelakantan, P. A Novel Small Molecule, 1,3-di-mtolyl-urea, Inhibits and Disrupts Multispecies Oral Biofilms. Microorganisms 2020, 8, 1261. [CrossRef] [PubMed]

44. Stepanović, S.; Vuković, D.; Hola, V.; Di Bonaventura, G.; Djukić, S.; Cirković, I.; Ruzicka, F. Quantification of Biofilm in Microtiter Plates: Overview of Testing Conditions and Practical Recommendations for Assessment of Biofilm Production by Staphylococci. APMIS 2007, 115, 891-899. [CrossRef]

45. Selinummi, J.; Seppälä, J.; Yli-Harja, O.; Puhakka, J.A. Software for Quantification of Labeled Bacteria from Digital Microscope Images by Automated Image Analysis. Biotechniques 2005, 39, 859-863. [CrossRef] [PubMed]

46. Fteita, D.; Könönen, E.; Söderling, E.; Gürsoy, U.K. Effect of Estradiol on Planktonic Growth, Coaggregation, and Biofilm Formation of the Prevotella intermedia Group Bacteria. Anaerobe 2014, 27, 7-13. [CrossRef] [PubMed]

47. Ramirez, T.; Shrestha, A.; Kishen, A. Inflammatory Potential of Monospecies Biofilm Matrix Components. Int. Endod. J. 2019, 52, 1020-1027. [CrossRef]

48. Pinkston, K.L.; Gao, P.; Diaz-Garcia, D.; Sillanpää, J.; Nallapareddy, S.R.; Murray, B.E.; Harvey, B.R. The Fsr Quorum-sensing System of Enterococcus faecalis Modulates Surface Display of the Collagen-binding MSCRAMM Ace through Regulation of gelE. J. Bacteriol. 2011, 193, 4317-4325. [CrossRef] [PubMed]

49. Dale, J.L.; Nilson, J.L.; Barnes, A.M.T.; Dunny, G.M. Restructuring of Enterococcus faecalis Biofilm Architecture in Response to Antibiotic-induced Stress. NPJ Biofilms Microbiomes 2017, 3, 15. [CrossRef]

50. Livak, K.J.; Schmittgen, T.D. Analysis of Relative Gene Expression Data Using Real-time Quantitative PCR and the 2(-Delta Delta C(T)) Method. Methods 2001, 25, 402-408. [CrossRef]

51. Shepard, B.D.; Gilmore, M.S. Differential Expression of Virulence-related Genes in Enterococcus faecalis in Response to Biological Cues in Serum and Urine. Infect. Immun. 2002, 70, 4344-4352. [CrossRef]

52. He, Z.; Liang, J.; Zhou, W.; Xie, Q.; Tang, Z.; Ma, R.; Huang, Z. Effect of the Quorum-Sensing luxS Gene on Biofilm Formation by Enterococcus faecalis. Eur. J. Oral Sci. 2016, 124, 234-240. [CrossRef]

53. Kumar, S.; Kumari, R.; Mishra, S. Pharmacological Properties and their Medicinal Uses of Cinnamomum: A Review. J. Pharm. Pharmacol. 2019, 71, 1735-1761. [CrossRef] [PubMed]

54. Yanakiev, S. Effects of Cinnamon (Cinnamomum spp.) in Dentistry: A Review. Molecules 2020, 25. [CrossRef] [PubMed]

55. Firmino, D.F.; Cavalcante, T.T.A.; Gomes, G.A.; Firmino, N.C.S.; Rosa, L.D.; de Carvalho, M.G.; Catunda, F.E.A., Jr. Antibacterial and Antibiofilm Activities of Cinnamomum Sp. Essential Oil and Cinnamaldehyde: Antimicrobial Activities. Sci. World J. 2018, 2018, 7405736. [CrossRef] [PubMed]

56. Vasconcelos, N.G.; Croda, J.; Simionatto, S. Antibacterial Mechanisms of Cinnamon and Its Constituents: A Review. Microb. Pathog. 2018, 120, 198-203. [CrossRef] [PubMed]

57. Huang, Z.; Pang, D.; Liao, S.; Zou, Y.; Zhou, P.; Li, E.; Wang, W. Synergistic Effects of Cinnamaldehyde and Cinnamic Acid in Cinnamon Essential Oil against S. pullorum. Ind. Crop. Prod. 2021, 162, 113296. [CrossRef]

58. Utchariyakiat, I.; Surassmo, S.; Jaturanpinyo, M.; Khuntayaporn, P.; Chomnawang, M.T. Efficacy of Cinnamon Bark Oil and Cinnamaldehyde on anti-multidrug resistant Pseudomonas aeruginosa and the Synergistic Effects in Combination with Other Antimicrobial Agents. BMC Complement. Altern. Med. 2016, 16, 158. [CrossRef] 
59. Honraet, K.; Goetghebeur, E.; Nelis, H.J. Comparison of Three Assays for the Quantification of Candida Biomass in Suspension and CDC Reactor Grown Biofilms. J. Microbiol. Methods 2005, 63, 287-295. [CrossRef]

60. Kuhn, D.M.; Balkis, M.; Chandra, J.; Mukherjee, P.K.; Ghannoum, M.A. Uses and Limitations of the XTT Assay in Studies of Candida Growth and Metabolism. J. Clin. Microbiol. 2003, 41, 506-508. [CrossRef]

61. Kitagawa, H.; Izutani, N.; Kitagawa, R.; Maezono, H.; Yamaguchi, M.; Imazato, S. Evolution of Resistance to Cationic Biocides in Streptococcus mutans and Enterococcus faecalis. J. Dent. 2016, 47, 18-22. [CrossRef]

62. Wang, S.; Wang, H.; Ren, B.; Li, H.; Weir, M.D.; Zhou, X.; Oates, T.W.; Cheng, L.; Xu, H.H.K. Do Quaternary Ammonium Monomers Induce Drug Resistance in Cariogenic, Endodontic and Periodontal Bacterial Species? Dent. Mater. 2017, 33, 1127-1138. [CrossRef]

63. Schwarz, S.R.; Hirsch, S.; Hiergeist, A.; Kirschneck, C.; Muehler, D.; Hiller, K.A.; Maisch, T.; Al-Ahmad, A.; Gessner, A.; Buchalla, W.; et al. Limited antimicrobial Efficacy of Oral Care Antiseptics in Microcosm Biofilms and Phenotypic Adaptation of Bacteria upon Repeated Exposure. Clin. Oral Investig. 2021, 25, 2939-2950. [CrossRef]

64. Beema Shafreen, R.M.; Selvaraj, C.; Singh, S.K.; Karutha Pandian, S. In Silico and In Vitro Studies of Cinnamaldehyde and Their Derivatives against LuxS in Streptococcus pyogenes: Effects on Biofilm and Virulence Genes. J. Mol. Recognit. 2014, 27, 106-116. [CrossRef] [PubMed]

65. Ahmed, S.; Rudden, M.; Smyth, T.J.; Dooley, J.S.G.; Marchant, R.; Banat, I.M. Natural Quorum Sensing Inhibitors Effectively Downregulate Gene Expression of Pseudomonas aeruginosa Virulence Factors. Appl. Microbiol. Biotechnol. 2019, 103, $3521-3535$. [CrossRef]

66. Ali, L.; Goraya, M.U.; Arafat, Y.; Ajmal, M.; Chen, J.L.; Yu, D. Molecular Mechanism of Quorum-Sensing in Enterococcus faecalis: Its Role in Virulence and Therapeutic Approaches. Int. J. Mol. Sci. 2017, 18, 960. [CrossRef]

67. Hancock, L.E.; Perego, M. The Enterococcus faecalis Fsr Two-component System Controls Biofilm Development through Production of Gelatinase. J. Bacteriol. 2004, 186, 5629-5639. [CrossRef]

68. Karygianni, L.; Ren, Z.; Koo, H.; Thurnheer, T. Biofilm Matrixome: Extracellular Components in Structured Microbial Communities. Trends Microbiol. 2020, 28, 668-681. [CrossRef] [PubMed]

69. Flemming, H.C.; Wingender, J. The Biofilm Matrix. Nat. Rev. Microbiol. 2010, 8, 623-633. [CrossRef] [PubMed]

70. Brackman, G.; Defoirdt, T.; Miyamoto, C.; Bossier, P.; Van Calenbergh, S.; Nelis, H.; Coenye, T. Cinnamaldehyde and Cinnamaldehyde Derivatives Reduce Virulence in Vibrio spp. by Decreasing the DNA-Binding Activity of the Quorum Sensing Response Regulator LuxR. BMC Microbiol. 2008, 8, 149. [CrossRef] [PubMed]

71. Upadhyay, A.; Upadhyaya, I.; Kollanoor-Johny, A.; Venkitanarayanan, K. Antibiofilm Effect of Plant Derived Antimicrobials on Listeria monocytogenes. Food Microbiol. 2013, 36, 79-89. [CrossRef] [PubMed]

72. Jett, B.D.; Huycke, M.M.; Gilmore, M.S. Virulence of Enterococci. Clin. Microbiol. Rev. 1994, 7, 462-478. [CrossRef]

73. Park, S.Y.; Kim, K.M.; Lee, J.H.; Seo, S.J.; Lee, I.H. Extracellular Gelatinase of Enterococcus faecalis Destroys a Defense System in Insect Hemolymph and Human Serum. Infect. Immun. 2007, 75, 1861-1869. [CrossRef]

74. Steck, N.; Hoffmann, M.; Sava, I.G.; Kim, S.C.; Hahne, H.; Tonkonogy, S.L.; Mair, K.; Krueger, D.; Pruteanu, M.; Shanahan, F.; et al. Enterococcus faecalis Metalloprotease Compromises Epithelial Barrier and Contributes to Intestinal Inflammation. Gastroenterology 2011, 141, 959-971. [CrossRef]

75. Cox, C.R.; Coburn, P.S.; Gilmore, M.S. Enterococcal Cytolysin: A Novel Two Component Peptide System that Serves as a Bacterial Defense against Eukaryotic and Prokaryotic Cells. Curr. Protein Pept. Sci. 2005, 6, 77-84. [CrossRef]

76. Jett, B.D.; Jensen, H.G.; Nordquist, R.E.; Gilmore, M.S. Contribution of the pAD1-encoded Cytolysin to the Severity of Experimental Enterococcus faecalis Endophthalmitis. Infect. Immun. 1992, 60, 2445-2452. [CrossRef] [PubMed]

77. Huycke, M.M.; Gilmore, M.S. Frequency of Aggregation Substance and Cytolysin Genes among Enterococcal Endocarditis Isolates. Plasmid 1995, 34, 152-156. [CrossRef]

78. Anderson, A.C.; Jonas, D.; Huber, I.; Karygianni, L.; Wölber, J.; Hellwig, E.; Arweiler, N.; Vach, K.; Wittmer, A.; Al-Ahmad, A. Enterococcus faecalis from Food, Clinical Specimens, and Oral Sites: Prevalence of Virulence Factors in Association with Biofilm Formation. Front. Microbiol. 2015, 6, 1534. [CrossRef] [PubMed]

79. Mohamed, J.A.; Huang, W.; Nallapareddy, S.R.; Teng, F.; Murray, B.E. Influence of Origin of Isolates, especially Endocarditis Isolates, and Various Genes on Biofilm Formation by Enterococcus faecalis. Infect. Immun. 2004, 72, 3658-3663. [CrossRef] [PubMed]

80. Bourgogne, A.; Garsin, D.A.; Qin, X.; Singh, K.V.; Sillanpaa, J.; Yerrapragada, S.; Ding, Y.; Dugan-Rocha, S.; Buhay, C.; Shen, H.; et al. Large-Scale Variation in Enterococcus faecalis Illustrated by the Genome Analysis of Strain OG1RF. Genome Biol. 2008, 9, R110. [CrossRef]

81. Pillai, S.K.; Sakoulas, G.; Gold, H.S.; Wennersten, C.; Eliopoulos, G.M.; Moellering, R.C., Jr.; Inouye, R.T. Prevalence of the fsr Locus in Enterococcus faecalis Infections. J. Clin. Microbiol. 2002, 40, 2651-2652. [CrossRef]

82. Nakayama, J.; Chen, S.; Oyama, N.; Nishiguchi, K.; Azab, E.A.; Tanaka, E.; Kariyama, R.; Sonomoto, K. Revised Model for Enterococcus faecalis Fsr Quorum-Sensing System: The Small Open Reading Frame fsrD Encodes the Gelatinase BiosynthesisActivating Pheromone Propeptide Corresponding to Staphylococcal Agrd. J. Bacteriol. 2006, 188, 8321-8326. [CrossRef]

83. Sifri, C.D.; Mylonakis, E.; Singh, K.V.; Qin, X.; Garsin, D.A.; Murray, B.E.; Ausubel, F.M.; Calderwood, S.B. Virulence Effect of Enterococcus faecalis Protease Genes and the Quorum-Sensing Locus fsr in Caenorhabditis elegans and Mice. Infect. Immun. 2002, 70, 5647-5650. [CrossRef] 
84. Balasubramanian, A.R.; Vasudevan, S.; Shanmugam, K.; Lévesque, C.M.; Solomon, A.P.; Neelakantan, P. Combinatorial Effects of Trans-cinnamaldehyde with Fluoride and Chlorhexidine on Streptococcus mutans. J. Appl. Microbiol. 2021, 130, $382-393$. [CrossRef]

85. Thomas, V.C.; Hiromasa, Y.; Harms, N.; Thurlow, L.; Tomich, J.; Hancock, L.E. A Fratricidal Mechanism is Responsible for eDNA Release and Contributes to Biofilm Development of Enterococcus faecalis. Mol. Microbiol. 2009, 72, 1022-1036. [CrossRef] [PubMed]

86. Strateva, T.; Atanasova, D.; Savov, E.; Petrova, G.; Mitov, I. Incidence of Virulence Determinants in Clinical Enterococcus faecalis and Enterococcus faecium Isolates Collected in Bulgaria. Braz. J. Infect. Dis. 2016, 20, 127-133. [CrossRef]

87. Lins, R.X.; de Oliveira Andrade, A.; Hirata Junior, R.; Wilson, M.J.; Lewis, M.A.; Williams, D.W.; Fidel, R.A. Antimicrobial Resistance and Virulence Traits of Enterococcus faecalis from Primary Endodontic Infections. J. Dent. 2013, 41, 779-786. [CrossRef] [PubMed]

88. Barbosa-Ribeiro, M.; De-Jesus-Soares, A.; Zaia, A.A.; Ferraz, C.C.; Almeida, J.F.; Gomes, B.P. Antimicrobial Susceptibility and Characterization of Virulence Genes of Enterococcus faecalis Isolates from Teeth with Failure of the Endodontic Treatment. J. Endod. 2016, 42, 1022-1028. [CrossRef] [PubMed]

89. Federle, M.J.; Bassler, B.L. Interspecies Communication in Bacteria. J. Clin. Investig. 2003, 112, 1291-1299. [CrossRef]

90. Schauder, S.; Shokat, K.; Surette, M.G.; Bassler, B.L. The LuxS Family of Bacterial Autoinducers: Biosynthesis of a Novel Quorum-Sensing Signal Molecule. Mol. Microbiol. 2001, 41, 463-476. [CrossRef]

91. Brackman, G.; Celen, S.; Hillaert, U.; Van Calenbergh, S.; Cos, P.; Maes, L.; Nelis, H.J.; Coenye, T. Structure-activity Relationship of Cinnamaldehyde Analogs as Inhibitors of AI-2 based Quorum Sensing and their Effect on Virulence of Vibrio spp. PLoS ONE 2011, 6, e16084. [CrossRef]

92. Geisinger, E.; Chen, J.; Novick, R.P. Allele-Dependent Differences in Quorum-Sensing Dynamics Result in Variant Expression of Virulence Genes in Staphylococcus aureus. J. Bacteriol. 2012, 194, 2854-2864. [CrossRef]

93. Yang, Y.; Li, W.; Hou, B.; Zhang, C. Quorum sensing LuxS/autoinducer-2 Inhibits Enterococcus faecalis Biofilm Formation Ability. J. Appl. Oral Sci. 2018, 26, e20170566. [CrossRef] [PubMed]

94. Doyle, A.A.; Stephens, J.C. A review of Cinnamaldehyde and Its Derivatives as Antibacterial Agents. Fitoterapia 2019, $139,104405$. [CrossRef] [PubMed]

95. Domadia, P.; Swarup, S.; Bhunia, A.; Sivaraman, J.; Dasgupta, D. Inhibition of Bacterial Cell Division Protein FtsZ by Cinnamaldehyde. Biochem. Pharmacol. 2007, 74, 831-840. [CrossRef] [PubMed] 